\title{
Anuran responses to spatial patterns of agricultural landscapes in Argentina
}

\author{
Romina P. Suárez • Maria E. Zaccagnini • Kimberly J. Babbitt • \\ Noela C. Calamari - Guillermo S. Natale - Alexis Cerezo • \\ Nadia Codugnello - Teresa Boca - Maria J. Damonte • \\ Josefina Vera-Candioti • Gregorio I. Gavier-Pizarro
}

Received: 25 February 2015/ Accepted: 28 July 2016/Published online: 13 August 2016

(C) Springer Science+Business Media Dordrecht 2016

\begin{abstract}
Context Amphibians are declining worldwide and land use change to agriculture is recognized as a leading cause. Argentina is undergoing an agriculturalization process with rapid changes in landscape structure.

Objectives We evaluated anuran response to landscape composition and configuration in two landscapes of east-central Argentina with different degrees of agriculturalization. We identified sensitive species
\end{abstract}

Electronic supplementary material The online version of this article (doi:10.1007/s10980-016-0426-2) contains supplementary material, which is available to authorized users.

R. P. Suárez $(\varangle) \cdot$ M. E. Zaccagnini ·

M. J. Damonte · G. I. Gavier-Pizarro

Biodiversidad, Ecología y Gestión Ambiental en

Agroecosistemas (BIOEGA), Instituto de Recursos

Biológicos (IRB), Instituto Nacional de Tecnología

Agropecuaria (INTA), Centro Nacional de

Investigaciones Agropecuarias (CNIA), De los Reseros y

Nicolás Repetto s/n, Hurlingham (1686), Buenos Aires,

Argentina

e-mail: suarez.romina@inta.gob.ar

\section{K. J. Babbitt}

Department of Natural Resources and the Environment, University of New Hampshire, Durham, NH 03861, USA

\section{N. C. Calamari}

Instituto Nacional de Tecnología Agropecuaria (INTA), EEA Paraná, Factores Bióticos y Protección Vegetal, Ruta

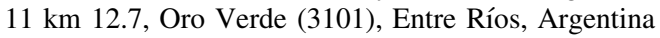

and evaluated landscape influence on communities and individual species at two spatial scales.

Methods We compared anuran richness, frequency of occurrence, and activity between landscapes using call surveys data from 120 sampling points from 2007 to 2009 . We evaluated anuran responses to landscape structure variables estimated within 250 and 500-m radius buffers using canonical correspondence analysis and multimodel inference from a set of candidate models.

Results Anuran richness was lower in the landscape with greater level of agriculturalization with reduced amount of forest cover and stream length. This pattern
A. Cerezo
Asociación Aves Argentinas, Matheu 1246, Buenos Aires, Argentina
A. Cerezo
Departamento de Métodos Cuantitativos, Facultad de Agronomía, Universidad de Buenos Aires, Av. San Martín 4453, CP 1417 Buenos Aires, Argentina
N. Codugnello
Laboratorio de Ecología, Universidad Nacional de Luján, Ruta 5 y Constitución, Luján (6700), Buenos Aires, Argentina
G. S. Natale
Centro de Investigaciones del Medio Ambiente,
Departamento de Química, Facultad de Ciencias Exactas, Universidad Nacional de La Plata, Calle 47 y 115 (s/n), La Plata, Buenos Aires, Argentina 
was driven by the lower occurrence and calling activity of seven out of the sixteen recorded species. Four species responded positively to the amount of forest cover and stream habitat. Three species responded positively to forest cohesion and negatively to rural housing. Two responded negatively to crop area and diversity of cover classes.

Conclusions Anurans within agricultural landscapes of east-central Argentina are responding to landscape structure. Responses varied depending on species and study scale. Life-history traits contribute to responses differences. Our study offers a better understanding of landscape effects on anurans and can be used for land management in other areas experiencing a similar agriculturalization process.

Keywords Amphibian conservation - Agriculture expansion and intensification - Entre Rios - Espinal · Landscape structure $\cdot$ Habitat loss $\cdot$ Forest connectivity $\cdot$ Landscape heterogeneity

\section{Introduction}

World population growth and food demand is leading to an agriculturalization process in many countries, which involves rapid changes in land use and promotes environmental degradation (Rabinovich and Torres 2004; Young 2006). This process is characterized by the expansion and intensification of land production areas that results in landscapes with reduced natural vegetation distributed in remnant patches and greater technology use to enhance production yields (Viglizzo et al. 2001; Aizen et al. 2009; Oesterheld 2008).

\section{T. Boca}

Instituto de Clima y Agua, Instituto Nacional de Tecnologia Agropecuaria (INTA), Centro Nacional de Investigaciones Agropecuarias (CNIA), De los Reseros y Nicolás Repetto s/n Hurlingham (1686), Buenos Aires, Argentina

J. Vera-Candioti

Instituto Nacional de Tecnología Agropecuaria (INTA)

A.E.R., Venado Tuerto, Santa Fe, Argentina

J. Vera-Candioti

Consejo Nacional de Investigaciones Científicas y

Técnicas (CONICET), Ciudad Autónoma de Buenos

Aires, Argentina
In Argentina, agriculture expansion and intensification occurs primarily in the Pampas and Espinal ecoregions (Viglizzo et al. 2003), which are the most productive regions in the country. Natural vegetation, such as forests and grasslands are reduced and replaced by row crop production expansion (Tassi et al. 2011). Although there are several important crops in these regions, soybean production is the main driver of the agriculturalization process (Young 2006) and the dominant type of row crop (FAOSTAT 2014; SAGPYA 2014).

Therefore, agricultural landscapes show a lower land-use diversity and heterogeneity (Aizen et al. 2009). Also, greater input of agrochemical products to enhance production is observed (Pérez Leiva and Anastasio 2003; Zaccagnini et al. 2007a; Bernardos and Zaccagnini 2011; CASAFE 2014). As a consequence, the composition and spatial configuration of agricultural landscapes are changing, altering the integrity and sustainability of agroecosystems (Zaccagnini et al. 2007b; De la Fuente and Suárez 2008; Aizen et al. 2009) and resulting in loss of biodiversity in the region (Schrag et al. 2009; Gavier-Pizarro et al. 2012).

Biodiversity conservation is an essential consideration for sustainable agroecosystems (Altieri 1999). Of special concern in agroecosystems are amphibians, which play key ecological roles in ecosystem functioning (Seale 1980; Wyman 1998; Marcot and Vander Heyden 2001). In agroecosystems, adult stages are valuable as biological pest controllers for agriculture production (Attademo et al. 2005), and are considered good biological indicators because they respond quickly to environmental change (EPA 2002). Many amphibian species are declining worldwide and habitat loss, fragmentation and degradation by agriculture have been recognized as leading factors in several countries (Bishop and Pettit 1992; Sparling 2002). In Argentina, these factors are also expected to affect amphibian conservation in agroecosystems, but effects of landscape change through agriculturalization are still not clear. Agriculturalization generates landscapes with varying levels of transformation. By comparing these different landscapes, we can better understand how amphibians respond to agricultural expansion and intensification by identifying sensitive species and key factors that determine their persistence (Pulliam 1988; Opdam 1990).

Many amphibians have a biphasic life cycle requiring both aquatic and terrestrial natural habitats 
for reproduction, larval development, feeding, hibernation and dispersal processes (Heyer et al. 1994). Thus, the availability, quality and connectivity of required habitats are fundamental for their persistence in agroecosystems. Recent international research on the relationships between amphibians and landscape attributes indicate that habitat loss and fragmentation exert strong negative effects on amphibians (Cushman 2006). Forest area surrounding ponds (Knutson et al. 1999; Houlahan et al. 2000; Herrmann et al. 2005), proximity of ponds to forests and distance among ponds (Guerry and Hunter 2002; Veysey et al. 2011) as well as connectivity of both ponds and forested habitats (Hecnar and M'Closkey 1996; Marsh and Trenham 2001; Rothermel 2004) were identified as key predictors of regional viability of amphibian populations. Several studies demonstrate that local and landscape changes resulting from agricultural expansion have negative effects on amphibian diversity (Babbitt et al. 2003; Silva et al. 2012). Further, crop expansion (Bonin et al. 1997; Mensing et al. 1998; Atauri and de Lucio 2001) and urban development (Carr and Fahrig 2001; Gagné and Fahrig 2007) can reduce amphibian richness and abundance.

Amphibian species respond differentially to landscape change in agricultural landscapes. Both negative and positive effects have been observed at species and guild levels (Bascompte and Solé 1996; Knutson et al. 1999; Joly et al. 2001). These studies suggest that amphibian response to landscape composition and configuration could depend on the interaction between species' life-history traits and the level of agricultural expansion. Anurans are the most diverse order of amphibians and include species with a variety of lifestyles from fully aquatic, semi-aquatic (aquatic and terrestrial), terrestrial, arboreal, and fossorial (Dodd 2010). Fully aquatic species may be more affected by direct changes to ponds than semi-aquatic or more terrestrial species that are not restricted to ponds and can move to find better habitat or shelter (Peltzer et al. 2006). These local scale impacts on reproductive habitat may have a stronger influence on species with low dispersal and low reproductive rates given their limited perception of space, low ability to colonize distant breeding sites, and thus, low population recruitment (Quesnelle et al. 2014). Alternatively, forest-dependent anurans may show greater sensitivity to forest habitat loss than habitat-generalist or open land species (Basso 1990). Also, more mobile forest- dependent anurans may show greater sensitivity to forest loss and fragmentation in the surrounding landscape matrix (Gibbs 1998) than highly mobile habitat-generalist species or less mobile forest-dependent species. Thus, it is important to study agricultural effects on anurans at the community and species levels at multiple scales to better understand the differential response of each species (Cushman 2006).

Our aim was to evaluate the effect of agriculturalization and resulting landscape structure on anurans in Argentina. Thus, we compared anuran responses patterns between two agricultural landscapes with different levels of agriculture expansion and intensification and evaluated the relation to landscape composition and configuration. We used these two agricultural landscapes as a proxy to represent a gradient of landscapes changes occurring during the agriculturalization process. Considering anuran life history traits mentioned above, we predicted the following relationships: (1) anuran richness, species frequency of occurrence and level of activity (anuran response variables) would be lower in highly transformed landscapes, (2) anuran response variables would be positively associated with landscapes having closer proximity of water bodies, greater amount of forest cover, greater proximity and connectivity of forest habitat patches and increased landscape heterogeneity, and conversely, negatively associated with greater row-crop production area and rural/urban housing density and proximity, and (3) individual species would show differential sensitivity to the agriculturalization process and show different associations to a different set of landscape variables based on their specific habitat requirements and life history traits.

\section{Methods}

Study area

We selected two primarily agricultural landscapes of $900 \mathrm{~km}^{2}$ near the towns of Crespo $\left(32^{\circ} 1^{\prime} \mathrm{S}, 60^{\circ} 17^{\prime} \mathrm{W}\right)$ and Cerrito $\left(31^{\circ} 4^{\prime} \mathrm{S}, 60^{\circ} 1^{\prime} \mathrm{W}\right)$, in the west-central part of Entre Rios province, east Argentina (Fig. 1). These areas belong to the Espinal ecoregion where rapid agricultural expansion is occurring. The original vegetation of these landscapes are semi-xerophytic forests, characterized by tree species such as Prosopis 


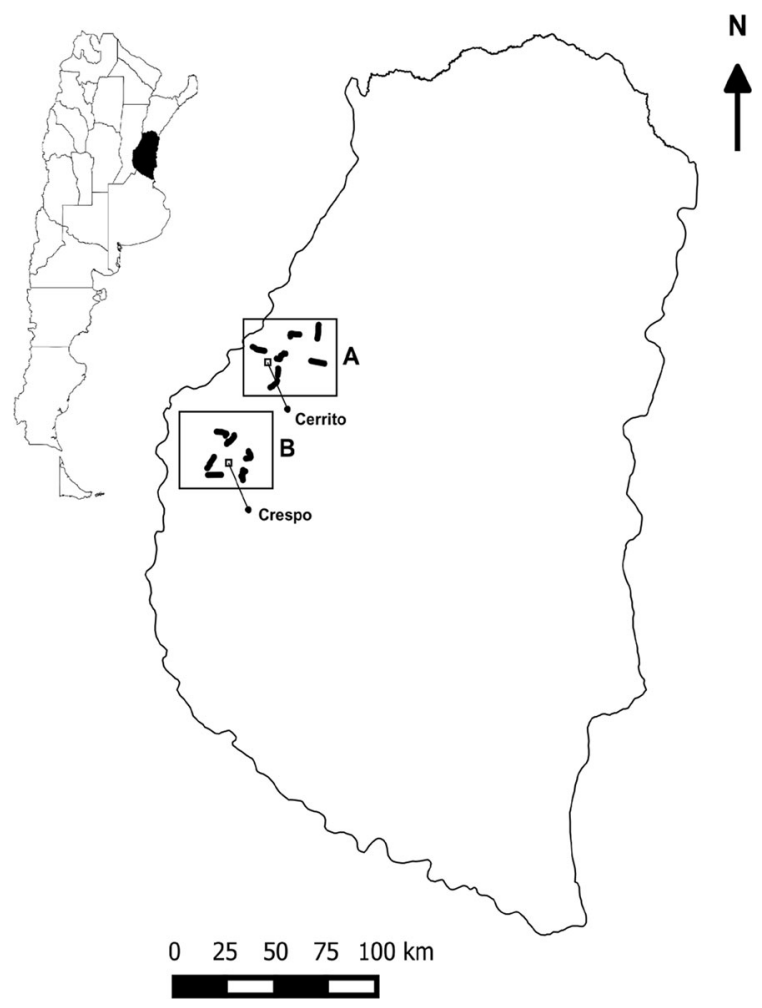

Fig. 1 Study area located in the west central portion of Entre Ríos province in Argentina. Selected landscapes with less (a) and more (b) agriculture expansion and intensification located near Cerrito $\left(31^{\circ} 4^{\prime} \mathrm{S}, 60^{\circ} 1^{\prime} \mathrm{W}\right)$ and Crespo Towns $\left(32^{\circ} 1^{\prime} \mathrm{S}, 60^{\circ} 17^{\prime} \mathrm{W}\right)$ respectively. Sampling transects are shown as black lines within study areas

affinis, Acacia caven, Geoffroea decorticans, Celtis tala and Schinus longifolia, intermixed with grasslands dominated by Stipa spp. and Paspalum dilatatum (Cabrera 1971; Sabattini et al. 1999, 2008). The climate is temperate with mean annual temperatures and precipitations ranging from 18 to $20^{\circ} \mathrm{C}$ and 800 to $1000 \mathrm{~mm}$ respectively.

Landscapes represent two stages of the agriculturalization process and differ in the amount and connectivity of forests, degree of spatial heterogeneity (i.e. presence of different elements in the landscape), and environmental quality of aquatic and forest habitats as defined by their degree of contamination or composition and structure of their vegetation cover (Calamari et al. 2006; Sabattini et al. 2009; Tassi et al. 2011). More intensive agriculture occurs around Crespo, an area with a longer history of agricultural use resulting in severe landscape simplification due to the expansion of row crops such as soybean, wheat, corn, and sunflower, planted pastures, and urban and large-rural settlements. Native forest cover has been greatly reduced and almost eliminated from this landscape (Sabatini et al. 2010). Forest environments consist primarily of remnant patches of native forest surrounding waterbodies, and small patches of exotic species planted for house landscaping and cattle shading. Less intensive agriculture occurs in the Cerrito landscape. This landscape has greater landcover heterogeneity, forest connectivity and more and larger patches of native semi-xerophytic forests. Also most hedgerows, erosion control terraces and riparian strips are covered by native forest compared to those in Crespo dominated by herbaceous vegetation (Calamari et al. 2006). The hydrologic network is dense in both landscapes and several waterbodies with different hydrologic regimes are present, including streams (the most common), rivers, lagoons, temporary natural ponds, permanent artificial ponds, and roadside ditches.

\section{Anuran survey}

Call surveys are a cost-efficient means of assessing anuran distributions throughout large areas and are commonly used in large-scale monitoring projects (Bishop et al. 1997; Bonin et al. 1997; LePage et al. 1997). We used the anuran call catalog of Straneck et al. (1993) and the North American Amphibian Monitoring Program (NAAMP) protocol (Weir and Mossman 2005) to conduct frog and toad call surveys at 60 sampling points located systematically on six transects per landscape placed on secondary roads $(N=120)$ (Fig. 2). Call surveys were performed five times per point within 7-day sampling periods (two transects per night) across 3 years, beginning from spring 2007-summer 2009. In the southern hemisphere, most anurans breed from September to March (i.e. spring and summer seasons), so sampling periods followed rain events during months with higher amphibian activity, i.e. October-November and February-March. Unidentified calls were resolved by visual observations of the calling individual at the sampling point when possible.

We located sampling points at least $800 \mathrm{~m}$ apart to ensure spatial independence of amphibian detection (Semlitsch and Bodie 2003). Three observers conducted call surveys but the main observer was the same among sampling periods to minimize differences 
in detection abilities. Call surveys lasted 3 min and were conducted after sunset and finished by midnight (Shirose et al. 1997; Gooch et al. 2006). Our sampling scheme did not allow us to meet the 'closed population' assumption necessary to calculate detection probabilities and occupancy because sampling occurred across years and migration and/or colonization processes might take place at sampled points (MacKenzie et al. 2003; Mackenzie and Royle 2005). Potential biases in occurrence estimation could be introduced by using naïve occurrence. However, we assert that five sampling periods per site within 7 days reduced bias. Thus, we obtained presence-absence data for each anuran species at each sampling point by pooling data from all sampling periods to calculate species richness, composition, frequency of occurrence and activity level. The presence of two pairs of species: (1) Physalaemus biligonigerus and P. albonotatus and (2) Dendropsophus nanus and D. sanborni were grouped for this study as Physalaemus spp. and Dendropsophus spp. respectively, because their calls are too similar to distinguish between in the field. We calculated species richness as the accumulated number of detected species after five surveys at each point. We used the proportion of sampling points occupied as a measure of each species frequency of occurrence within each landscape (i.e., high, moderate, and low frequency occurrence). We used the maximum activity-calling index value registered per sampling point after five surveys as an index of relative abundance of males (Weir and Mossman 2005). The activity calling index was 0 if no individual called, 1 when we could count the number of calling individuals, 2 if we could distinguish calls but they overlapped, and 3 when we detected a chorus of calling individuals. Maximum activity-calling index of 3 also implies breeding activity. Anuran richness and species presence-absence data at the sampling point were used to model their relationship with landscape structure variables. Only species detected by call surveys in at least $15 \%$ of total sampling points in at least one of the studied landscapes were considered for presence-absence modelling.

Landscape analysis and explanatory variables

We used a Landsat satellite image obtained from a fusion process of one multispectral Landsat TM image of $30 \mathrm{~m}$ of spatial resolution (Path 226-Row 82 January 2007, including bands 1-5 and 7) and the panchromatic band from a Landsat ETM + image of $15 \mathrm{~m}$ of spatial resolution (January 2003) to increase the spatial resolution (Pohl and Van Genderen 1998; Calamari et al. 2006) for landscape analysis (Fig. 2). Those images were downloaded from INPE web site (Brazilian National Institute for Space Research). Before the fusion process the images were geometrically corrected using a first degree polynomial model because the topography of the study area is flat plain or with smooth undulations. Also, images were orthorectified using a digital elevation model (DEM) and nearest neighbor as resample method. Subsequently, we used Principal Component as a method for fusion process with nearest neighbor as resampling technique.

The resulting image was then classified using the parametric supervised classification algorithm maximum likelihood. Nine terrestrial land cover types were identified, and classification was validated with 100 points per land cover type randomly selected using Quickbird images (available in GoogleEarth TM, http://earth.google.com) and ground sampling (Congalton and Green 2009). Any pixel clump smaller than 0.5 ha was considered a classification artifact and was eliminated from the classified image. Overall classification accuracy was $82 \%$ and the most misclassified cover type was corn (Supplementrary material Appendix 1). We grouped the nine land cover types into four classes: (1) row crops (soybean, corn, sunflower and sorghum), (2) forests, (3) grasslands, pastures and harvested fields with stubble cover, and (4) urban areas, roads, bare ground and harvested fields with no stubble cover (Fig. 2). The completed process was carried out in ERDAS imagine 9.2 (2008).

We established a 250 and 500-m buffer around each sampling point, and calculated landscape composition and configuration variables using FRAGSTAT (version 3.3, McGarigal et al. 2012) (Fig. 2, Supplementrary material Appendix 2). We selected these buffer sizes to include core terrestrial habitat and migration distances registered for anurans that range from 205 to $360 \mathrm{~m}$ (Semlitsch and Bodie 2003). Within each buffer, we calculated the Shannon diversity classes Index (SHDI) as a measure of landscape heterogeneity, total cover area of row crops (CA1) as a measure of row-crop production level, total forest cover (CA2), and number (NP2), cohesion (COHES2), mean area (AREA2) and mean euclidean distance (ENN2) of 

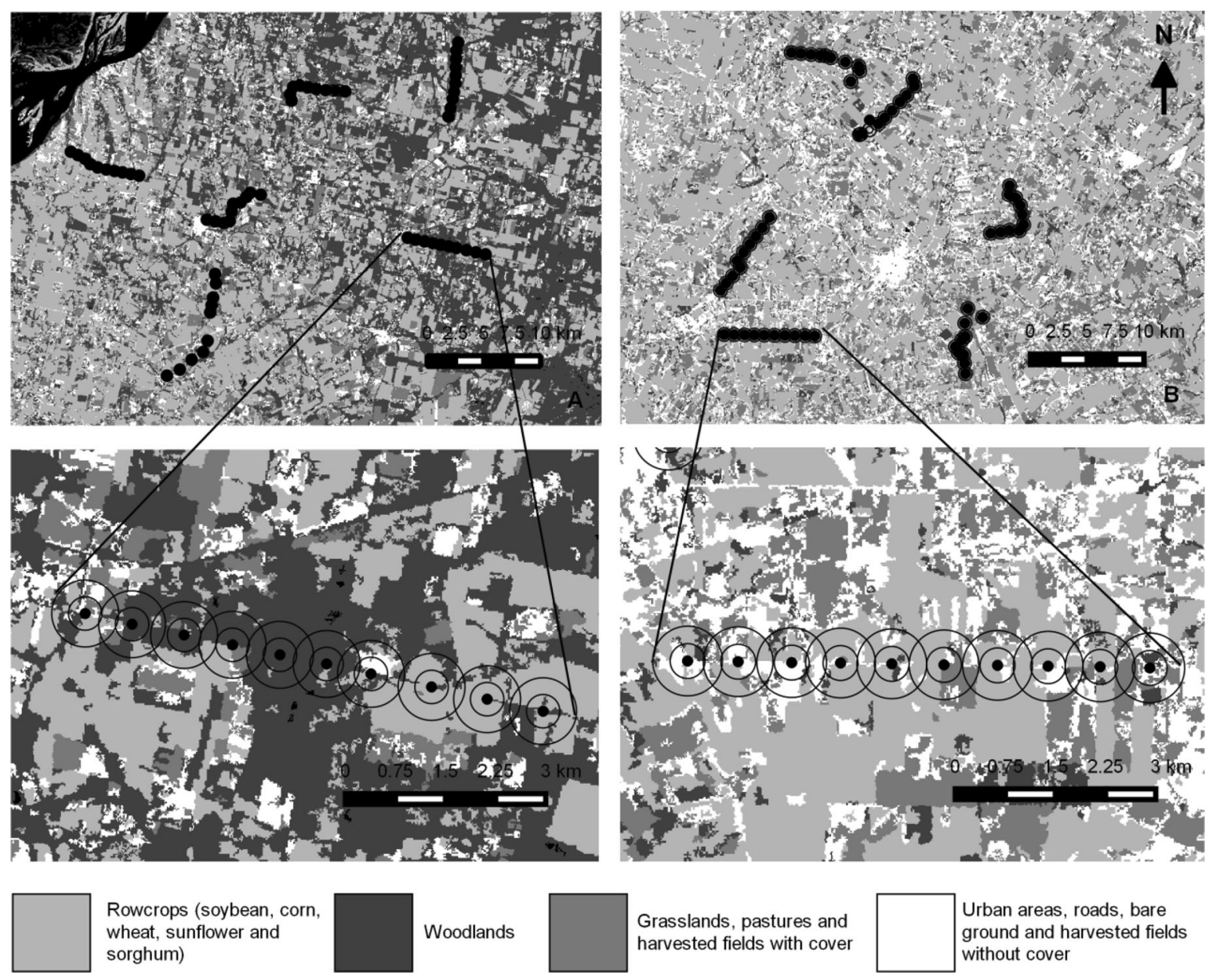

Fig. 2 Land cover classification of a Landsat TM image around (a) Cerrito and (b) Crespo towns showing distribution of sampling transects and points with 250-500 buffer areas

forest patches, as indicator of forested habitat loss and fragmentation for anurans.

To quantify the availability and proximity of potential aquatic breeding areas, we calculated the total number of different water bodies (WB), total length of stream sections (STREAM) within each buffer, and the distance to the nearest water body from the sampling site (DISTWB). We also measured ruralhousing influence by quantifying total number of rural establishments, i.e. rural houses, within each buffer (RE) and distance to the nearest rural establishment (DISTRE). Visual recognition and quantification of these elements was performed using Quickbird imagery available through the Google Earth site (http://earth.google.com) using QGIS 2.0 (QGIS Development Team 2012) since most water bodies and individual rural establishments could not be defined in the classified Landsat ETM + image.

Landscape structure and anuran diversity comparison between landscapes

To evaluate landscape structure and anuran status differences between the two landscapes, we compared landscape variables measured at two spatial scales (250 and $500 \mathrm{~m}$ ), species richness and level of activity recorded at the sampling point using unpaired t-tests $(\alpha=0.01)$. To compare each species frequency of occurrence between the landscapes, we used Chi square $\left(\chi^{2}\right)$ tests. Statistical assumptions of normality, homoscedasticity and data independence were evaluated and met. 
Response of anurans to landscape structure

We explored the association of each species presence to landscape structure variables using canonical correspondence analysis in $\mathrm{R}$ using vegan package ( $\mathrm{R}$ Development Core Team 2013) to group species based on similar responses to the landscape structure (Legendre and Legendre 1998). We used univariate regression analyses to explore the relationship of species presenceabsence and sampling point species richness (response variables) relationship with each landscape variable.

We examined the correlation among landscape explanatory variables by Pearson tests at each scale of analysis using a tolerance level of $r=0.7$. Correlated variables with less statistical significance were discarded (Belsley et al. 1980). AREA2 was highly correlated with CA2 $(r=0.981)$ as well as WB and DISTWB $(\mathrm{r}=0.705)$ at the $250 \mathrm{~m}$-scale. AREA2 was also correlated with CA2 at $500 \mathrm{~m}(\mathrm{r}=0.946)$. Thus, we discarded AREA2 at both scales and WB at $250 \mathrm{~m}$ from further analyses. Final variables to include in further analyses were selected according to correlation analyses and the strength of their fit obtained by the univariate regression analysis with each response variable.

We analyzed anuran relationship with landscape composition and configuration at two spatial scales by fitting generalized linear mixed models for anuran richness and species presence in $\mathrm{R}$ version 3.2.1 (glmmML package, $\mathrm{R}$ Development Core Team 2013). Landscape and sampling transect entered the model as random effects (Zuur et al. 2009). We modeled richness as a poisson process (i.e. counts), and species presence as a binomial process, i.e. logistic regression. Species presence modeling was run only for the species whose frequency of occurrence differed between the landscapes but had at least $15 \%$ of sampling points occupied within any of the studied landscapes.

We created a candidate set of a priori models for richness and species presence data using ecologically meaningful landscape variables at each scale (Table 1). Landscape variables were standardized before modeling. As we have a limited knowledge of the biology and ecology of several of the analyzed species, we fit the same set of models for all the species trying to represent all plausible relationships between anurans and landscape structure.

We used the second-order Akaike Information Criterion (AICc, recommended when $\mathrm{n} / \mathrm{K}<40$, where $n$ is the sample size and $K$ is the number of estimated parameters) and Akaike weights $\left(\mathrm{w}_{\mathrm{i}}\right)$ to choose best-fitting models from the candidate set of models (Burnham and Anderson 1998; Anderson et al. 2000; Burnham and Anderson 2001). The AIC belongs to a family of model selection criteria which consider model fit as well as complexity, and permits the simultaneous comparison of multiple models (Johnson and Omland 2004). AIC values reflect the amount of "lost information" when a model is used to approximate conceptual reality. Consequently, the model with the lowest AIC value is selected as the best model (Burnham and Anderson 1998). When differences between AIC values are small (i.e., less than 2 AIC units), Akaike weights can be used as a measure of the "weight of evidence" in favor of each model. Akaike weights are interpreted as the approximate probability that model $\mathrm{i}$ is the best-fitting model in the set of models being considered (Anderson et al. 2000).

To evaluate the effect of landscape composition and configuration, we used multi-model inference or "model averaging" (Burnham and Anderson 1998, 2001). For richness and individual species, we obtained model coefficient averages, interpreted as the average effects of each landscape predictor variable, weighted by Akaike weights. These model averages were obtained from the "confidence set" of models which was defined as those with less than 2 AIC units of difference with the best model (Burnham and Anderson 1998, 2001). Model selection parameters were calculated in $\mathrm{R}$ using MuMIn package ( $\mathrm{R}$ Development Core Team 2013).

\section{Results}

Landscape composition and configuration

Less intensified landscape near Cerrito showed significantly greater forest cover (CA2) and mean area (AREA2), number (NP2) and cohesion (COHES2) of patches as well as lower cover of row crops (CA1) than the most intensified landscape found near Crespo at both spatial scales (Table 2). Density of rural establishments (RE) within $250 \mathrm{~m}$, their proximity (DISTRE) and mean euclidean nearest-neighbour distance of forest patches (ENN2) within $500 \mathrm{~m}$, also differed between landscapes, being greater in the more intensified landscapes around Crespo. The diversity of cover classes (SHIDI), total number of water bodies 
Table 1 General structure of a priori models evaluated for anuran richness and species presence

\begin{tabular}{ll}
\hline Models & General model structure \\
\hline Null & None \\
Single-factor & Aquatic habitat (STREAM; WB and/or DISTWB) \\
& Forested habitat (CA2) \\
& Row crop production (CA1) \\
& Heterogeneity (SHDI) \\
& Connectivity $($ COHES2, ENN2 and/or NP2) \\
& Rural housing $($ RE and DISTRE) \\
& Aquatic habitat + forested habitat \\
& Aquatic habitat + row crop production \\
& Aquatic habitat + heterogeneity \\
& Aquatic habitat + connectivity \\
& Aquatic habitat + rural housing \\
Multiple-factor & Forested habitat + heterogeneity \\
& Forested habitat + connectivity \\
& Forested habitat + connectivity + heterogeneity \\
& Forested habitat + heterogeneity + rural housing \\
& Forested habitat + connectivity + heterogeneity + rural housing \\
& Forested habitat + rural housing \\
& Aquatic habitat + forested habitat + heterogeneity \\
& Aquatic habitat + forested habitat + connectivity \\
& Aquatic habitat + forested habitat + rural housing \\
& Aquatic habitat + forested \\
& habitat + heterogeneity + connectivity + rural housing \\
Full-Factor & \\
& \\
& \\
& \\
&
\end{tabular}

(WB), total length of stream sections (STREAM) and distance to closest water bodies (DISTWB) did not differ between landscapes at either scale.

Anuran species presence, level of activity, and richness

We confirmed the presence of 18 species in the less intensified agricultural landscape near Cerrito area and 15 species in the more intensified landscape near Crespo by call surveys (Table 3). Physalaemus riograndensis and $S$. acuminatus were not detected in Crespo area and the presence of $P$. albonotatus and Dendropsophus nanus was uncertain in this area. The last two species show great calling similarity with $P$. billigonigerus and $D$. sanborni respectively, thus we decided to group these species as Physalaemus spp. and Dendropsophus spp. for further comparisons.

The less intensified landscape showed significantly greater mean total richness and less variability than within the more intensified landscape $(t=4.0526$, $\mathrm{df}=116.48, \mathrm{p}<0.0001)$. Mean total richness at sampling points was $7.06 \pm 1.56$ (mean $\pm \mathrm{SE}$ ) ranging from 5 to 12 species around Cerrito and $5.83 \pm 1.66$ ranging from 3 to 12 species around Crespo.

The proportion of points occupied per species differed between landscapes as well (Fig. 3a). We distinguished three groups of species' frequency of occurrence: 1) high frequency of occurrence species in both landscapes with more than $75 \%$ of sampling points occupied ( $\mathrm{n}=4$ : Leptodactylus gracilis, L. mystacinus, L. latinasus, Hypsiboas pulchellus), 2) moderate to low frequency of occurrence species that occupied between 15 and $75 \%$ of sampling points showing a higher occurrence in the less intensified area $(\mathrm{n}=7$ : Rhinella schneideri, R. fernandezae, Scinax nasicus, S. squalirostris, Dendropsophus sp., Pseudopaludicola falcipes and Physalaemus spp.) and 3) rare frequency of occurrence species with less than $15 \%$ of sampling points occupied in each landscape $(n=4)$, one species with a slightly higher occurrence in highly modified landscapes (Odontophrynus americanus) and three 


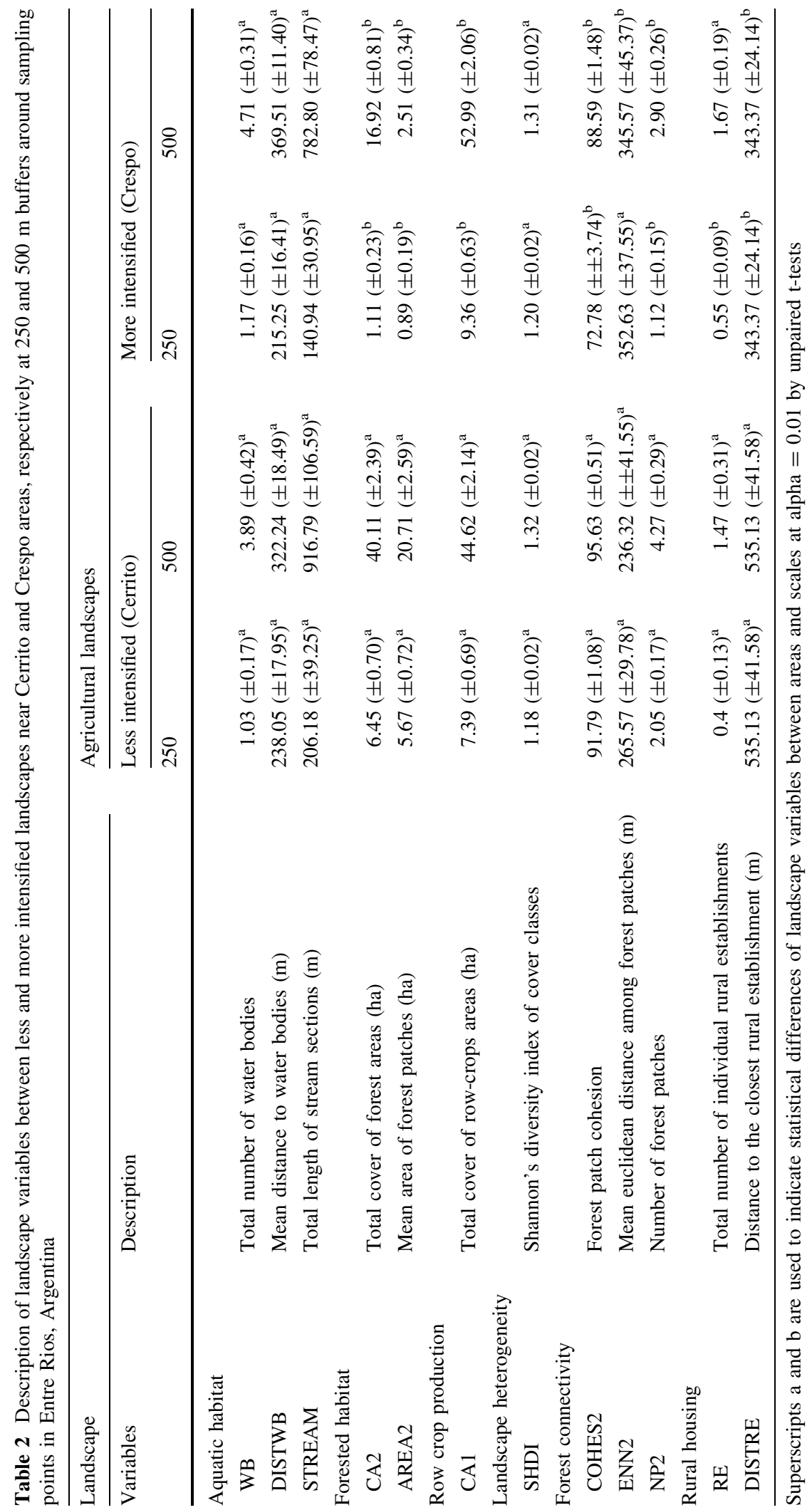


species with a slightly higher frequency of occurrence in less modified landscapes ( $R$. arenarum, Elachistocleis bicolor and $P$. riograndensis). Five species (33\%) were significantly found in more sampling points in the less intensified area: $R$. schneideri $\left(\chi^{2}=19.86, \mathrm{p}<0.001\right)$, $R$. fernandezae $\left(\chi^{2}=6.4, \quad \mathrm{p}<0.05\right), \quad S$. nasicus $\left(\chi^{2}=8, \mathrm{p}<0.005\right)$, Physalaemus spp. $\left(\chi^{2}=20.84\right.$, $\mathrm{p}<0.001)$ and $P$. riograndensis $\left(\chi^{2}=6.31, \mathrm{p}<0.05\right)$. Finally, S. squalirostris and Dendropsophus sp showed a marginally higher occurrence in the less intensified area $\left(\chi^{2}=3.06 ; \mathrm{p}=0.08\right.$ for both species).

Among the detected species, nine species (60\%) showed differences in the maximum activity level reached per sampling point between agricultural

Table 3 Anuran species detected by calling and visual surveys at sampling points in less and more intensified landscapes near Cerrito and Crespo areas

\begin{tabular}{|c|c|c|}
\hline Species & Cerrito & Crespo \\
\hline \multicolumn{3}{|l|}{ Bufonidae } \\
\hline R. schneideri & $X$ & $\mathrm{X}$ \\
\hline R. fernandezae & $X$ & $\mathrm{X}$ \\
\hline$R$. arenarum & $X$ & $X$ \\
\hline \multicolumn{3}{|l|}{ Cycloramphidae } \\
\hline O. americanus & $X$ & $X$ \\
\hline \multicolumn{3}{|l|}{ Hylidae } \\
\hline S. nasicus & $\mathrm{X}$ & $\mathrm{X}$ \\
\hline S. squalirostris & $X$ & $\mathrm{X}$ \\
\hline S. acuminatus & $\mathrm{X}$ & \\
\hline \multicolumn{3}{|c|}{ Dendropsophus spp.** } \\
\hline D. sanborni & $X$ & $\mathrm{X}$ \\
\hline D. nanus & $X$ & \\
\hline H. pulchellus & $X$ & $\mathrm{X}$ \\
\hline \multicolumn{3}{|l|}{ Leiuperidae } \\
\hline \multicolumn{3}{|l|}{ Physalaemus spp.* } \\
\hline P. albonotatus & $X$ & \\
\hline P. biligonigerus & $\mathrm{X}$ & $\mathrm{X}$ \\
\hline P. riograndensis & $\mathrm{X}$ & \\
\hline P. falcipes & $\mathrm{X}$ & $\mathrm{X}$ \\
\hline \multicolumn{3}{|l|}{ Leptodactylidae } \\
\hline L. latinasus & $\mathrm{X}$ & $\mathrm{X}$ \\
\hline L. mystacinus & $\mathrm{X}$ & $X$ \\
\hline L. gracilis & $X$ & $X$ \\
\hline \multicolumn{3}{|l|}{ Microhylidae } \\
\hline E. bicolor & $X$ & $\mathrm{X}$ \\
\hline
\end{tabular}

Species classified by family according to Vaira et al. 2012.* Grouped species: P.albonotatus and P. biligonigerus. ** Grouped species: D. sanborni and D. nanus landscapes: L. mystacinus $(\mathrm{t}=3.65, \mathrm{p}<0.001)$ and O. americanus $(\mathrm{t}=2.53, \mathrm{p}<0.05)$ were more active in Crespo area (more intensified landscape) while $S$. nasicus $(\mathrm{t}=6.83, \mathrm{p}<0.0001)$, Physalaemus spp. $(\mathrm{t}=7.10, \mathrm{p}<0.0001), \quad R . \quad$ schneideri $(\mathrm{t}=5.79$, $\mathrm{p}<0.0001)$, Dendropsophus spp. $(\mathrm{t}=2.26, \mathrm{p}<$ $0.05)$ y $P$. falcipes $(\mathrm{t}=2.67, \mathrm{p}<0.01)$, E. bicolor $(\mathrm{t}=2.19, \mathrm{p}<0.05)$ and $P$. riograndensis $($ Fig. 3B) were more active in Cerrito area (less intensified landscape). The calling activity level of species showed a very similar pattern than the one observed for the distribution of occurrence frequencies.

Landscape structure influence on anurans at community and species level

\section{Richness}

Site-level species richness was positively related to total cover of forests (CA2) at both buffer distances, and length of stream sections (STREAM) within 250-m (Fig. 4, Supplementrary material Appendix 3). STREAM_250 was present in $60 \%$ of the best models while CA2_250 and CA2_500 were in 53 and $27 \%$ respectively. Number of Forest patches at the 250-m scale (NP2_250), cohesion of forest patches at the 500-m scale (COHES2_500) and distance to rural establishments (DISTRE) also showed a positive influence on richness and were present in $13 \%$ of the models (Fig. 4).

\section{Species responses}

Canonical correspondence analysis (CCA) axes explained 25 and $26 \%$ of the variation at 250 and $500 \mathrm{~m}$ respectively indicating high variability in the data (Table 4). CCA axis 1 accounted for approximately $78 \%$ of the constrained variability at both scales indicating a strong gradient, while CCA axis 2 accounted for $8 \%$ of the constrained variability. CCA1 was most strongly influenced by total forest cover (CA2) and distance to rural establishments (DISTRE) at both scales.

Species formed two response groups in relation to the landscape variables. L. latinasus, $L$. mystacinus, $L$. gracilis and $H$. pulchellus (group 1) showed no association with any of the considered landscape variables. Due to this response pattern and the fact that they showed high frequency of occurrence and activity 
Fig. 3 Proportion of occupied sampling points (a) and maximum activity level values (b) per site per species detected by calling surveys between less (Cerrito area, white bars) and more intensified landscapes (Crespo area, black bars). Species codes: Leptodactylus latinasus $(\mathrm{Ll})$, L. mystacinus $(\mathrm{Lm}), \mathrm{L}$. gracilis $(\mathrm{Lg})$, Hypsiboas pulchellus (Hp), Scinax nasicus (Sn), Physalaemus spp. (Psp: Physalaemus albonotatus and $P$. billigonigerus), Rhinella schneideri (Rs), $R$.

fernandezae (Rf), $S$. squalirostris (Ss), Dendropsophus spp. (Dsp: Dendropsophus sanborni and D. nanus),

Pseudopaludicola falcipes $(P f), R$. arenarum $(R a)$,

Odontophrynus americanus (Oa), Elachistocleis bicolor (Eb) y Physalaemus riograndensis $(\mathrm{Pr})$. $* \mathrm{P}<0.05, * * \mathrm{P}<0.005$, $* * * \mathrm{P}<0.0001$
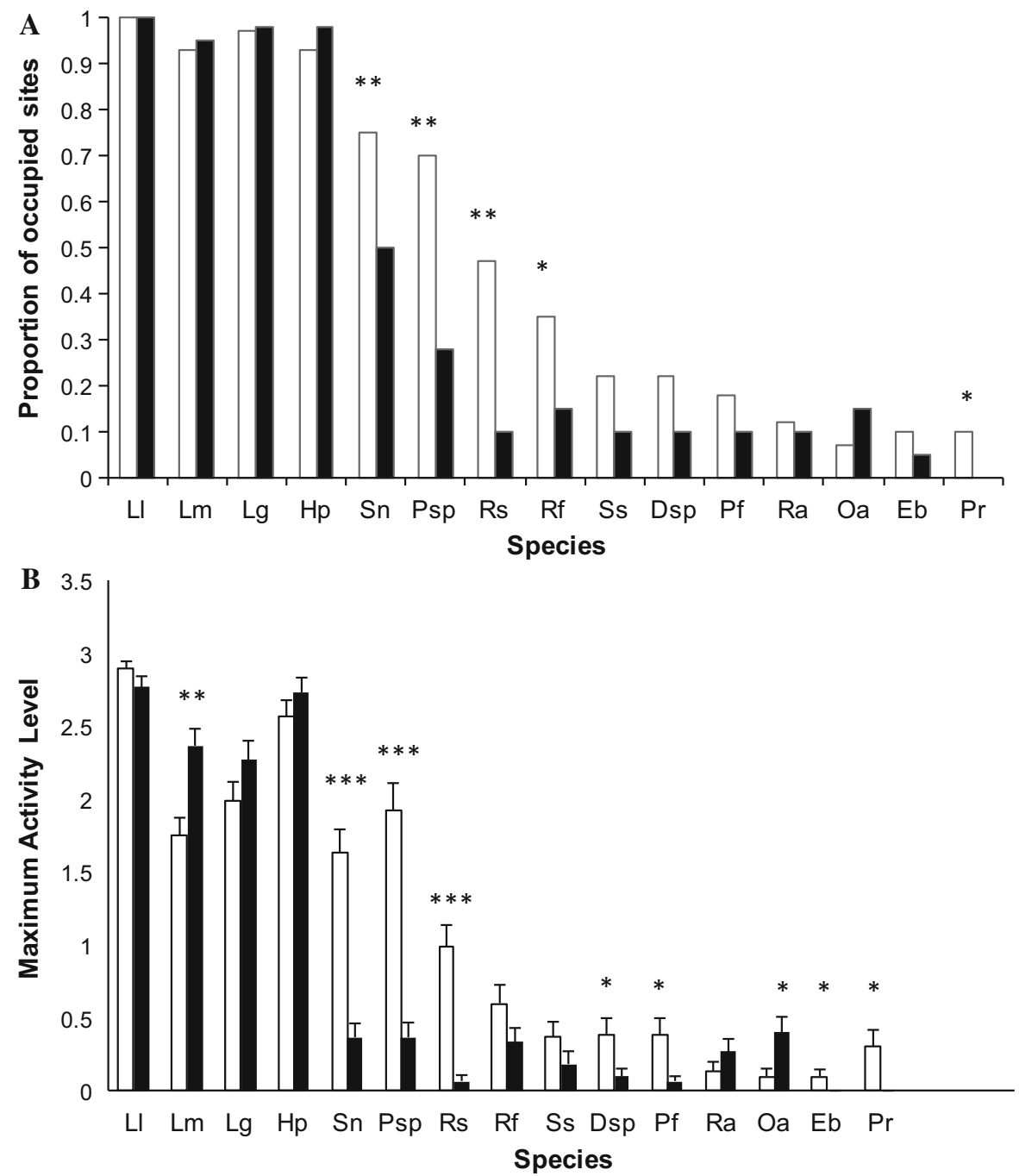

in both landscapes, these species were not analyzed further. The other group, Dendropsophus spp., Physalaemus spp., R. schneideri and R. fernandezae (group 2) showed an association to CA2 and DISTRE. Species in this group were more frequent in sampling points of less intensified landscape. S. nasicus, $S$. squalirostris and $P$. falcipes did not associate strongly with either group. However, S. nasicus showed similarities to both groups while $S$. squalirostris and P. falcipes were more similar to group 2 (Fig. 5).

According to individual species analyses, we observed that the presence of six out of seven amphibian species responded positively to aquatic habitat availability, where total length of stream (STREAM) was the more important type of aquatic habitat. Also, four of these species ( $S$. nasicus, Dendropsophus spp., Physalaemus spp. and $P$. falcipes) responded positively to forested habitat cover (CA2). Forest connectivity given by cohesion of forest patches (COHES2) was relevant for five species (Rhinella schneideri, R. fernandezae, Dendropsophus spp. and Physalaemus spp. and $P$. falcipes). $P$. falcipes was the only species that showed a negative response to this variable. Three species (Rhinella schneideri, Physalaemus spp. and S. nasicus) responded to landscape heterogeneity, i.e. diversity of cover classes (SHDI). S. nasicus was the only species that responded positively to this variable. In relation to human impact, rural housing (RE and DISTRE) and row crop production area (CA1) had 
Fig. 4 Relationship between landscape variables and anuran species presence at two spatial scales ( 250 and $500 \mathrm{~m}$ ). Averaged coefficients of more relevant variables that were included in the best set of models are shown (a) together with the proportion of models in the best set where those landscape variables were present (b). Position of averaged coefficients above or below zero indicates effect direction as positive or negative respectively

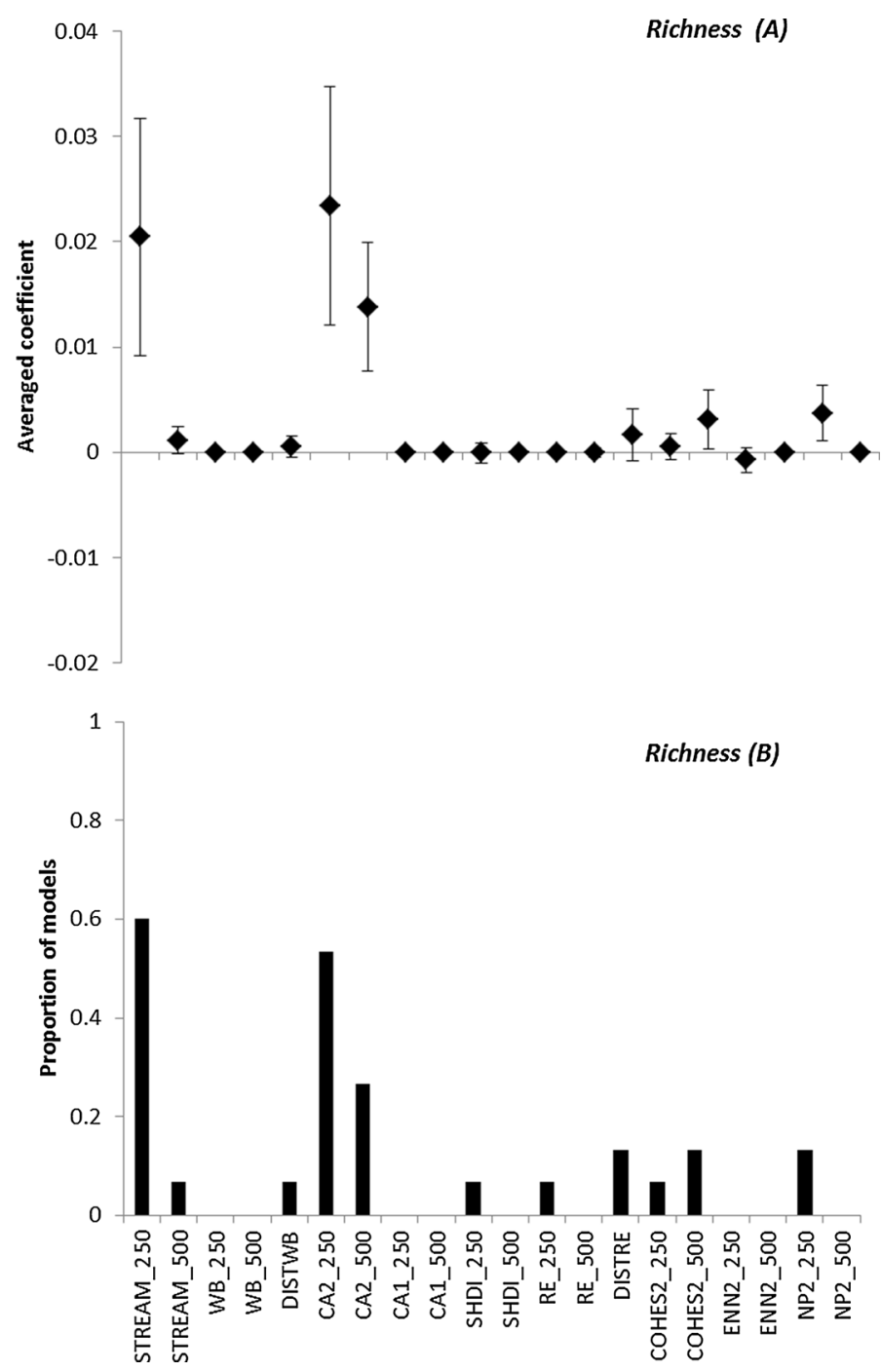

negative effects for two species (Rhinella schneideri and Dendropsophus spp.) (Fig. 6, Supplementrary material Appendix 3).

Regarding spatial scales we found that two species (S. squalirostris and Physalaemus spp.) were clearly related to landscape variables at the $250 \mathrm{~m}$ scale, four (R. schneideri, R. fernandezae, S. nasica and $P$. falcipes) at the $500 \mathrm{~m}$ scale and one (Dendropsophus spp.) to variables at both scales (Fig. 6, Supplementrary material Appendix 3).

$R$. schneideri was positively associated with the distance to rural establishments (DISTRE) and aquatic habitat availability (STREAM and WB) while negatively associated with number of rural houses (RE), diversity of cover classes (SHDI) and row crop production (CA1). Other landscape variables that did not have significant coefficients but appeared within the best set of models for this species were forest cohesion (COHES2) and terrestrial habitat availability (CA2). The main scale of response for this species was $500 \mathrm{~m}$.

$R$. fernandezae presence increased with forest cohesion (COHES2) within $500 \mathrm{~m}$. According to the frequency of these variables in the best set of models it also showed an association at the same scale, i.e. $500 \mathrm{~m}$, with aquatic (STREAM) and 
Table 4 Summary information for Canonical Correspondence Analysis (CCA) obtained at both spatial scales (250 and 500 $\mathrm{m}$ ). Output shows inertia (mean squared contingency coefficients) and proportion values that describe the explanatory power of the analysis given by considered landscape variables (constrained) and the unexplained "variance" (unconstrained), eigenvalues and importance of first and second CCA axes, and scores for landscape variables on CCA1 and CCA2

\begin{tabular}{llllll}
\hline & $250 \mathrm{~m}$ & & & $500 \mathrm{~m}$ & \\
\cline { 2 - 3 } \cline { 5 - 6 } & Inertia & Proportion & & Inertia & Proportion \\
\hline Total & 0.27 & 1.00 & & 0.27 & 1.00 \\
Constrained & 0.07 & 0.25 & & 0.07 & 0.26 \\
Unconstrained & 0.20 & 0.75 & & 0.20 & 0.74 \\
Eigenvalues & CCA1 & CCA2 & & CCA1 & CCA2 \\
& 0.05 & 0.005 & & 0.05 & 0.005 \\
& 0.79 & 0.08 & & 0.77 & 0.08 \\
Landscape variables & & & \\
SHDI & 0.11 & -0.04 & & 0.01 & 0.26 \\
CA1 & 0.15 & 0.21 & & 0.18 & 0.27 \\
CA2 & -0.50 & -0.57 & & -0.59 & -0.65 \\
NP2 & -0.31 & -0.48 & & -0.23 & -0.07 \\
ENN2 & 0.10 & 0.19 & & 0.12 & 0.02 \\
COHES2 & -0.28 & -0.29 & & -0.27 & -0.24 \\
RE & 0.13 & 0.43 & 0.06 & 0.33 \\
DistRE & -0.29 & -0.67 & -0.29 & -0.51 \\
DistWB & -0.05 & 0.11 & 0.10 & -0.08 \\
STREAM & -0.19 & -0.35 & -0.14 & -0.13 \\
\hline & & & &
\end{tabular}

forested habitat availability (CA2), diversity of cover classes (SHDI) and distance to rural establishments (DISTRE).

Scinax nasicus showed a positive response to terrestrial habitat availability (CA2) and diversity of cover classes (SHDI) at $500 \mathrm{~m}$ scale. A response to aquatic (STREAM) and the distance to rural establishments (DISTRE) was also observed in the best set of models.

On the other hand, the presence of $S$. squalirostris was only positively related to stream length within $250 \mathrm{~m}$ (STREAM). However, forest cover (CA2), distance to water bodies (DISTWB) and diversity of cover classes (SHDI) appeared also in the best set of models.

Dendropsophus spp. responded to a great number of landscape variables at both spatial scales. It responded positively to total length of stream sections (STREAM), forest cover (CA2), forest patch cohesion (COHES2), and negatively to cover of row crops (CA1). Other variables in the best set of models were: number of water bodies (WB), diversity of cover classes (SHDI), forest patches (NP2), proximity of forest patches (ENN2) and distance to rural establishments (DISTRE).

Physalaemus spp. showed a similar response pattern than Dendropsophus ssp although it was limited to the $250 \mathrm{~m}$ scale. Landscape variables associated positively with this species were: number and proximity of water bodies (WB and DISTWB), total length of stream sections (STREAM), forest area (CA2), number and cohesion of forest patches (NP2 and COHES2) and diversity of cover classes (SHDI).

Finally, P. falcipes was associated positively with total number of water bodies (WB), forest cover (CA2) and patch cohesion (COHES2). Other relevant variables were: cover of row crops (CA1), number (RE) and proximity (DISTRE) of rural establishments. This species showed a clear association to the $500 \mathrm{~m}$ spatial scale (Fig. 6, Supplementrary material Appendix 3).

\section{Discussion}

In west-central Entre Rios, landscape composition and configuration influenced the frequency of occurrence, and relative abundance of some anuran species, which influenced landscape-scale species richness patterns between two landscapes along the agricultural expansion and intensification gradient. The landscape with greater agricultural expansion and intensification had lower stream and forested habitats within 250 and $500 \mathrm{~m}$ of sampling points. While some species seems to be unaffected or adapting well to the new conditions, there is a subset of sensitive species that responded negatively to these reduced landscape features at different scales. Thus, changing anuran diversity patterns in east-central Argentina appear to be driven by the reduction in several key species, and at the sampling point scale, there is large diversity variation and potential for local extinctions that may result in more simplified anuran communities. 
Fig. 5 Canonical correspondence analysis plots showing association of species presence data and landscape variables at two scales: $250 \mathrm{~m}$ (a) and $500 \mathrm{~m}$ (b)
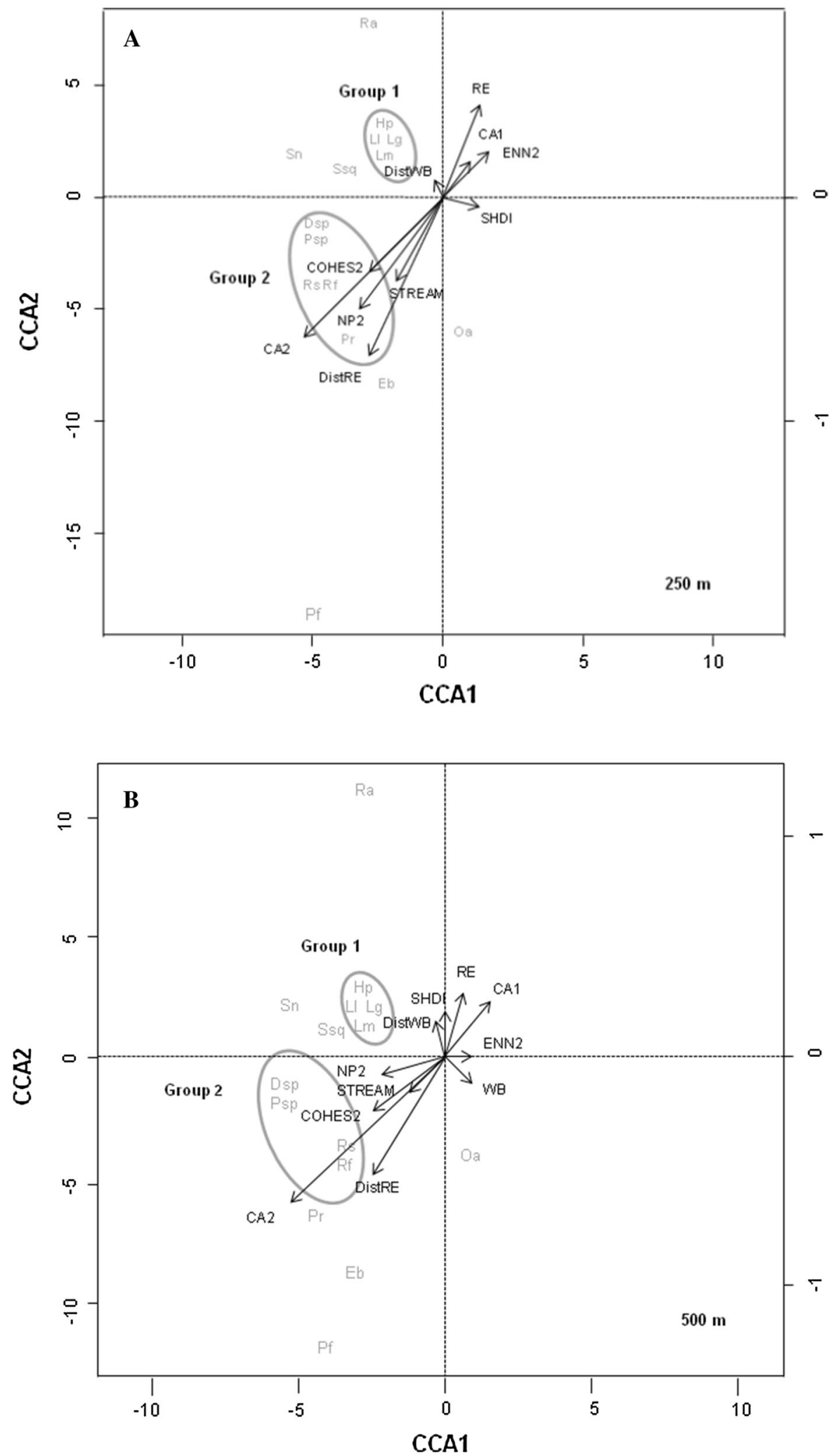
Fig. 6 Relationship between landscape variables and anuran species presence at two spatial scales ( 250 and $500 \mathrm{~m}$ ). Averaged coefficients of more relevant variables that were included in the best set of models are shown per species

(a) together with the proportion of models in the best set where those landscape variables were present (b). Position of averaged coefficients above or below zero indicates effect direction as positive or negative respectively
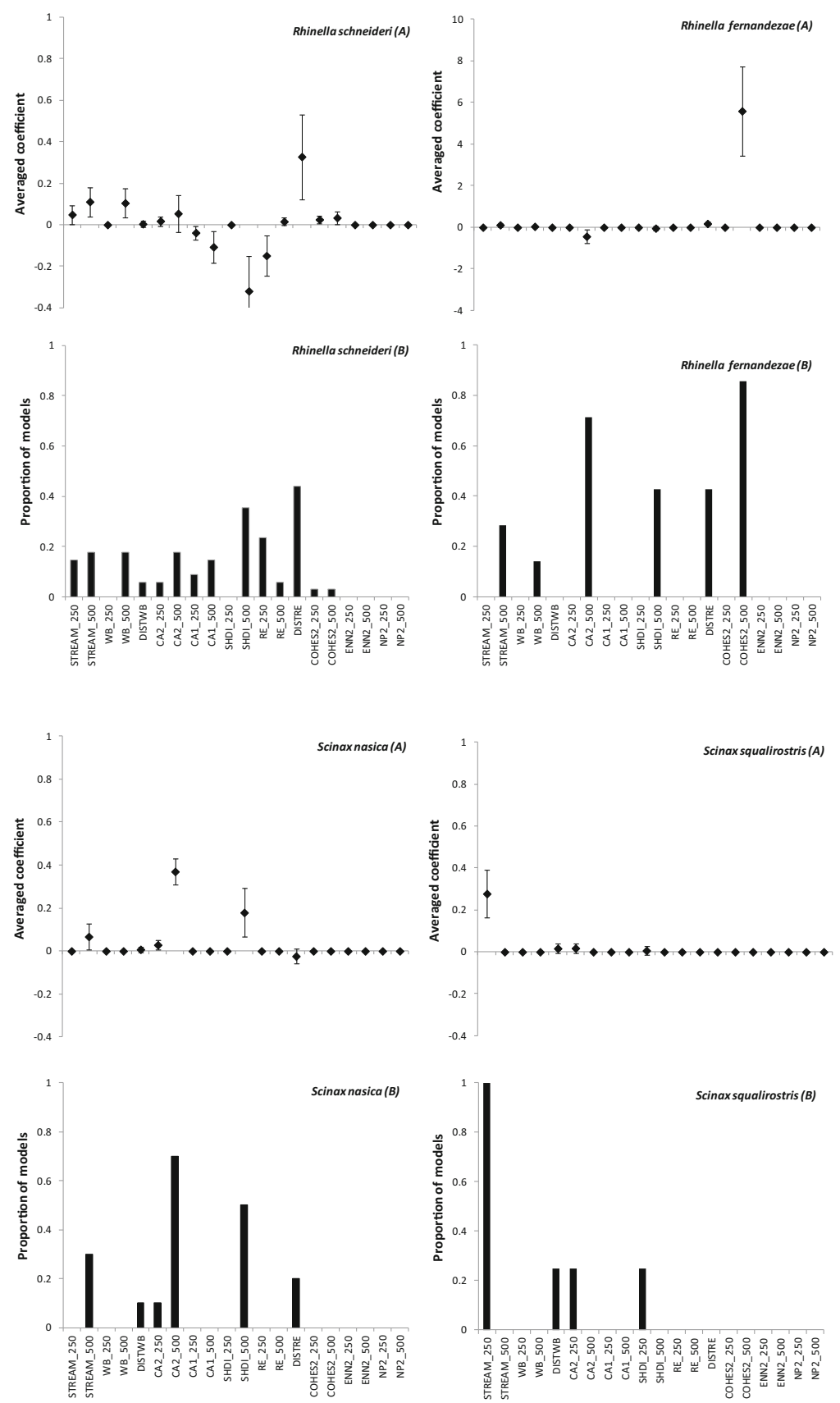

Anuran life history traits and landscape structure relationships

We identified four anuran species that tolerate high levels of agricultural expansion and intensification $(L$. latinasus, L. mystacinus, L. gracilis and H. pulchellus), seven 'sensitive' species (R. shneideri, R. fernandezae, S. nasicus, S. squalirostris, Dendropsophus spp.,
Physalaemus spp. and Pseudopaludicola falcipes) that respond negatively to high levels of agriculturalization, and four species that were 'rare' in both landscapes (i.e. $R$. arenarum, O. americanus, $E$. bicolor and $P$. riograndensis). In general, we observed that species within each group share common life history traits that may determine anurans response to landscape changes. 

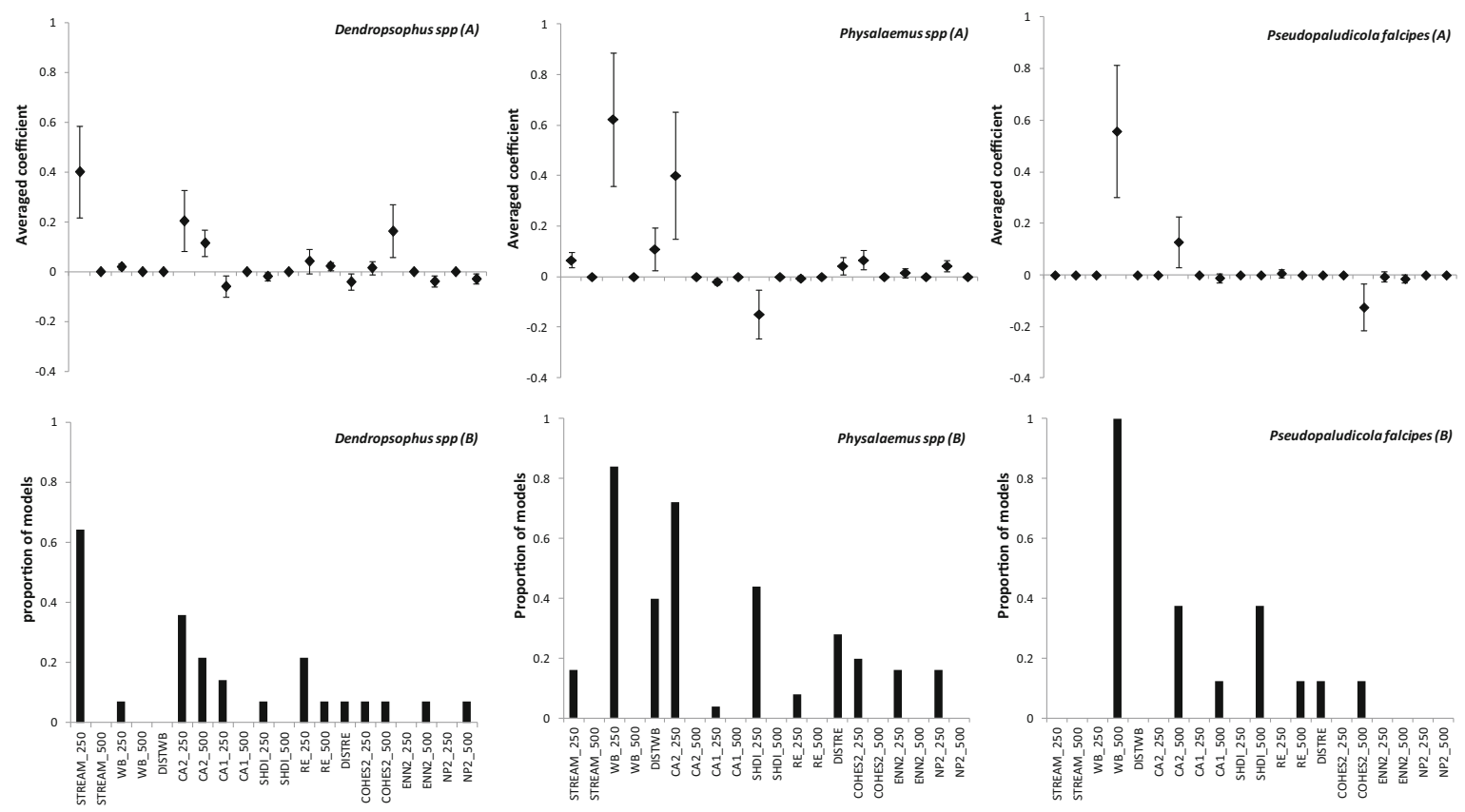

Fig. 6 continued

'Tolerant' species have life-history traits that might allow them to survive in intensified agricultural areas. Most are terrestrial-aquatic frogs ( $L$. latinasus, $L$. mystacinus and L. gracilis), breeding in open land temporary ponds (Cei 1980; Basso 1990) or laying eggs in foam nests inside caves that develop rapidly after heavy rains (Gallardo 1972, 1974; Achaval and Olmos 2003). H. pulchellus is a treefrog with longer larval stages but is a continuous breeder that uses a variety of water bodies (Peltzer and Lajmanovich 2007). These 'tolerant' species are also generalist predators, medium-to-large in size, and potentially good dispersers (Gallardo 1987; Basso 1990). Thus, they might detect optimal habitat from a great distance and persist despite habitat transformation (Zollner 2000; Mech and Zollner 2002). The activity patterns of 'tolerant' species showed interesting differences between studied landscapes. For example, L. mystacinus was more active in highly modified agricultural areas, which might indicate that certain levels of agriculture could represent more resources for this species as observed for $H$. pulchellus and L. gracilis. On the contrary, L. latinasus was less active suggesting it may be less adapted to such landscapes (Suárez and Zaccagnini 2004).
'Rare' species included two terrestrial-aquatic anurans with explosive breeding events of short duration or with breeding periods taken place every 2 or more years. For example, $P$. riograndensis shows 1 or 2 days of high breeding activity only after very heavy rains events and $O$. americanus also shows this breeding activity pattern but also it occurs every two years because tadpoles overwinter and metamorphose the following season (Isacch and Barg 2002; Martori et al. 2005). This feature confers very low detectability to these species and may explain their very low frequency of occurrence and activity level in both landscapes. $R$. arenarum and E. bicolor are more terrestrial and their rarity in this study was difficult to explain. The biology of E. bicolor is not well known (Martori et al. 2005) and $R$. arenarum shows a more regular pattern of breeding activity (Isacch and Barg 2002) and resembles the other two toad species considered as sensitive.

Among 'sensitive' species we found terrestrialaquatic frogs (Physalaemus spp., P. falcipes), toads (R. schneideri and R. fernandezae) and arboreal-aquatic species ( $S$. nasicus, S. squalirostris, Dendropsophus spp.) (Lajmanovich and Peltzer 2004; Dodd 2010). Their diet specificity and longer development stages may explain their lower frequency of occurrence in 
agricultural intensified landscapes as breeding habitat is lower and diversity of prey decreases (Lehtinen and Ramanamanjato 2006). Four 'sensitive' species ( $R$. schneideri, Physalaemus spp., P. falcipes and Dendropsophus spp.) may require stream habitats surrounded by forest habitat to fulfill their life history needs. This may be an evidence of 'landscape complementation effect', in that the persistence of anurans in highly fragmented landscapes may be constrained by the need for connectivity between aquatic breeding sites (i.e. streams) and suitable terrestrial habitat (i.e. forests) (Dunning et al. 1992; Rothermel 2004). Landscapes extremely modified by agriculture have less landscape complementation of required habitat types and these anurans might be unable to fulfill their life requirements. Rural housing density and proximity might negatively affect $R$. schneideri, Physalaemus spp. and Dendropsophus ssp because they may depend on breeding habitat that is rare in residential areas and undergo domestic animals predation, road mortality or even stream pollution by waste disposal (Carr and Fahrig 2001; Suárez, pers.obs).

Landscapes including longer sections of streams, especially headwaters and low order streams may favor six out of seven sensitive species (R. schneideri, $S$. nasica, S. squalirostris, Physalaemus spp., Dendrosophus spp. and P. falcipes). Although these species are considered pond-breeding anurans, most have a long larval development, higher risk of desiccation and prolonged exposure to agrochemicals (particularly around Crespo town). Few natural ponds, most with altered physical and chemical conditions, are present in this area (Suarez R.P. pers. obs.). Streams surrounded by forests might substitute ponds as good quality aquatic habitat in these highly modified landscapes (Suarez pers. obs; Forman 1995; Naiman et al. 2005; Williams 2008). Forest connectivity along and between streams might favor toad species such as $R$. fernandezae and $R$. schneideri by providing favorable conditions to move between breeding sites (Sinsch 1990; Rothermel 2004; Cushman et al. 2009). Toads have longer migration distances than other anurans (Semlitsch and Bodie 2003) ranging from 250 to $1000 \mathrm{~m}$ (Forester et al. 2006) and avoid open habitats probably due to higher predation risks (Rothermel and Semlitsch 2002).

Landscape structure influenced anuran species at two spatial scales. Main effects were similar at 250 and $500 \mathrm{~m}$ scales. However, species showed specific associations to spatial scale (Johnson et al. 2002; Price et al. 2004). This specificity might have some relation to body size. Three of the largest sensitive species $(R$. schneideri, $R$. fernandezae and $S$. nasicus) showed stronger association to landscape variables at $500 \mathrm{~m}$ while two of the smallest species ( $S$. squalirostris and Physalaemus spp.) did it at $250 \mathrm{~m}$. Larger anurans tend to travel farther (Semlitsch and Bodie 2003; Forester et al. 2006; Daversa et al. 2012) and are able to detect preferred habitats at greater distances (Zollner 2000).

Landscape structure and anuran assemblages

The response of amphibian richness to landscape structure changes produced by the expansion of agriculture was determined by the observed individual relationships. In general terms, anuran richness would be reduced by the loss of forests and streams mainly at the $250 \mathrm{~m}$ scale as shown in other studies regarding forests cover (Kolozsvary and Swihart 1999; Houlahan et al. 2000; Trenham and Shaffer 2005). The moderate-low variation of richness explained in our models might be explained by the number of species that were not related to landscape pattern.

We suggest that if our observed patterns between landscape and anuran diversity are maintained through time and landscape changes such as lower forest cover continues, the anuran community may become less diverse. Several species, i.e. Rhinella shneideri, $R$. fernandezae, Scinax nasicus, S. squalirostris, Dendropsophus spp., Physalaemus spp. and Pseudopaludicola falcipes, would be further affected and could experience local extinctions in highly modified agricultural landscapes in east-central Argentina. For example, the presence of $S$. acuminatus, P. limellum, L. elenae and T. typhonius was recorded in Enrique Berduc Rural Educational Park, one of the last remnants of the historic landscape without agricultural use between Crespo and Cerrito areas. These anurans should be found across the study area based on historical ranges (IUCN 2015), but our inability to detect after multiple visits may indicate some of these species have already undergone local extinctions.

\section{Conservation and management implications}

Our results present baseline patterns that can be used to help mitigate landscape changes in a substantial area of Entre Rios and the Espinal eco-region under 
heavy threat of rapid agricultural expansion and intensification, The future agricultural expansion in Entre Ríos will likely continue to exert negative impacts on anurans and the ecosystem services they provide (e.g. biological pest control, Attademo et al. 2005; Hocking and Babbitt 2014).

Based on our findings, landscapes that could provide more forest habitat within $500 \mathrm{~m}$ of streams would help mitigate local loss of species as this measure would assist the most sensitive species $(R$. schneideri, R.fernandezae, Physalaemus spp., Dendropsophus spp.). None of these species are categorized as vulnerable or threatened (Vaira et al. 2012; IUCN 2015). Thus, these species could be used as focus species in future monitoring studies to determine landscape change effects to provide valuable information for an accurate categorization.

Finally, recent development of the National Law 26331 on Minimum Standards for environment protection of native forests (Presupuestos Mínimos de Protección Ambiental de Bosques Nativos) provides a good opportunity to preserve and manage habitat for anuran conservation. Managers involved in land-use planning could include the relationships found in this study into landscape management recommendations to preserve the biodiversity of one of the most globally endangered biological groups.

Acknowledgments This research was fully funded by INTA, through the Projects AERN 2624 and 2622. We thank to the numerous farmers that kindly granted access to their properties and Cerrito town by offering us a field station where to stay during field sampling periods. We also want to thank the valuable fieldwork assistance provided by P. Calieres and L. Castañaga as well as the advice and helpful comments provided by J. Thompson, M.J Pizarro, B. Poliserpi, Y. Sica, L. Solari, J. Decarre and A. Goijman from INTA, K. Hodara from University of Buenos Aires, D. Hocking and J. Veysey from the University of New Hampshire. We also thank Deahn Donner, Veronique StLuis and an anonymous reviewer for valuable comments and suggestions in a previous version of the manuscript.

\section{References}

Achaval F, Olmos A (2003) Anfibios y reptiles del Uruguay, 2nd edn. Graphis Impresora, Montevideo

Aizen MA, Garibaldi LA, Dondo M (2009) Expansión de la soja y diversidad de la agricultura argentina. Ecol Austral 19(1):45-54

Altieri MA (1999) The ecological role of biodiversity in agroecosystems. Agric Ecosyst Environ 74:19-31
Anderson DR, Burnham KP, Thompson WL (2000) Null hypothesis testing: problems, prevalence, and an alternative. J Wildl Manag 64:912-923

Atauri JA, de Lucio JV (2001) The role of landscape structure in species richness distribution of birds, amphibians, reptiles and lepidopterans in Mediterranean landscapes. Landscape Ecol 16(2):147-159

Attademo A, Lajmanovich R, Peltzer P, Cejas W (2005) Amphibians occurring in soybean and implications for biological control in Argentina. Agric Ecosyst Environ 106:389-394

Babbitt KJ, Baber MJ, Tarr TL (2003) Patterns of larval amphibian distribution along a wetland hydroperiod gradient. Can J Zool 81:1539-1552

Bascompte J, Solé RV (1996) Habitat fragmentation and extinction thresholds in spatially explicit models. J Anim Ecol 65(4):465-473

Basso NG (1990) Estrategias adaptativas en una comunidad subtropical de anuros. Cuadernos de Herpetología. Series Monográficas 1:3-70

Belsley DA, Kuh E, Welsch RE (1980) Regression diagnostics: identifying influential data and sources of collinearity. Wiley, New York

Bernardos J, Zaccagnini ME (2011) El uso de insecticidas en cultivos agrícolas y su riesgo potencial para las aves en la región pampeana. Hornero 26(1):55-64

Bishop CA, Pettit KE (1992) Declines in Canadian amphibian populations: designing a national strategy. Canadian Wildlife Service, Ottawa, Ont. Occas. Pap. No. 76

Bishop CA, Pettit KE, Gartshore ME, Macleod DA (1997) Extensive monitoring of anuran populations using call counts and road transects in Ontario (1992 to 1993). In: Green DM (ed) Amphibians in decline: Canadian studies of a global problem. Society for the Study of Amphibians and Reptiles, St. Louis, pp 149-160

Bonin J, DesGranges L, Rodrigue J, Ouellet M (1997) Anuran species richness in agricultural landscapes of Quebec: foreseeing long-term results of road call surveys. In: Green DM (ed) Amphibians in decline: Canadian studies of a global problem. Society for the Study of Amphibians and Reptiles, St. Louis, pp 141-149

Brodeur JC, Suárez RP, Natale GS, Ronco A, Zaccagnini ME (2011) Frogs inhabiting intensive crop production areas of Argentina exhibit reduced body condition and a distinct pattern of enzyme alterations. Environ Health Saf 74(5):1370-1380

Burnham KP, Anderson DR (1998) Model selection and inference: a practical information-theoretic approach. Springer, New York

Burnham KP, Anderson DR (2001) Kullback-Leibler information as a basis for strong inference in ecological studies. Wildl Res 28:111-119

Cabrera AL (1971) Fitogeografía de la República Argentina. Bol Soc Argent Bot 14:1-42

Calamari NC, Lamfri M, Zaccagnini ME (2006) Aplicaciones de la teledetección y los sistemas de información geográfica al estudio de la fragmentación del bosque nativo entrerriano y sus efectos sobre las poblaciones de aves. Trabajo final de aplicación. Universidad de Luján

Cámara Argentina de Sanidad Agropecuaria y Fertilizantes [CASAFE] (2014) [Internet]. http://www.casafe.org/ biblioteca/estadisticas 
Carr LW, Fahrig L (2001) Effect of road traffic on two amphibian species of different vagility. Conserv Biol 15:1071-1078

Cei JM (1980) Amphibians of Argentina. Monitore Zool Ital (ns). Monogr 2, p 609

Congalton RG, Green K (2009) Assessing the accuracy of remotely sensed data: principles and practices. 2 nd ed

Cushman SA (2006) Effects of habitat loss and fragmentation on amphibians: a review and prospectus. Biol Conserv 128:231-240

Cushman SA, Compton BW, McGarigal K (2009) Chapter 20: Habitat fragmentation effects depend on complex interactions between population size and dispersal ability: modeling influences of roads, agriculture and residential development across a range of life-history characteristics. In: Huettmann F, Cushman SA (eds) Spatial complexity, informatics and wildlife conservation. Springer, Japan, pp 367-383

Daversa RD, Muths E, Bosch J (2012) Terrestrial movement patterns of the common toad (Bufo bufo) in central Spain reveal habitat of conservation importance. J Herpetol 46(4):658-664

De la Fuente EB, Suárez SA (2008) Problemas ambientales asociados a la actividad humana: la agricultura. Ecol Austral 18:239-252

Dodd CK Jr (ed) (2010) Amphibian ecology and conservation. A handbook of techniques. Oxford University Press, Oxford, p 556

Dunning JB, Danielson BJ, Pulliam HR (1992) Ecological processes that affect populations in complex landscapes. Oikos 65:169-175

Food and Agriculture Organization of the United Nations Statistics Division [FAOSTAT] (2014) [Internet]. http:// faostat3.fao.org/home/E

Forester DC, Snodgrass JB, Marsalek K, Lanham Z (2006) Postbreeding dispersal and summer home range of female american toads (Bufo americanus). Northeastern Nat 13(1):59-72

Forman RTT (1995) Land mosaics: the ecology of landscapes and regions. Cambridge University Press, Cambridge

Gagné SA, Fahrig L (2007) Effect of landscape context on anuran communities in breeding ponds in the National Capital Region, Canada. Landscape Ecol 22:205-215

Gallardo JM (1972) Anfibios de la provincia de Buenos Aires. Observaciones sobre ecología y zoogeografía. Ciencia e Investigación 28(1-2):3-14

Gallardo JM (1974) Anfibios de alrededores de Buenos Aires. EUDEBA, Buenos Aires

Gallardo JM (1987) Anfibios Argentinos. Guia para su identificación Ed. Biblioteca Mosaico

Gavier-Pizarro GI, Calamari NC, Thompson JJ, Canavelli SB, Solari LM, Decarre J, Goijman AP, Suarez RP, Bernardos JN, Zaccagnini ME (2012) Expansion and intensification of row crop agriculture in the Pampas and Espinal of Argentina can reduce ecosystem service provision by changing avian density. Agric Ecosyst Environ 154:44-55

Gibbs JP (1998) Distribution of woodland amphibians along a forest fragmentation gradient. Landscape Ecol 13:263-268

Gooch MM, Heupel AM, Price SJ, Dorcas ME (2006) The effects of survey protocol on detection probabilities and site occupancy estimates of summer breeding anurans. Appl Herpetol 3:129-142
Guerry AD, Hunter ML Jr (2002) Amphibian distributions in a landscape of forests and agriculture: an examination of landscape composition and configuration. Conserv Biol 16(3):745-754

Hecnar SJ (1997) Amphibian pond communities in southwestern Ontario. In: Green DM (ed) Amphibians in decline: Canadian studies of a global problem. Herpetological conservation 1. Society for the Study of Amphibians and Reptiles and Canadian Association of Herpetologists, St. Louis, MI, pp 1-15

Hecnar SJ, M'Closkey RT (1996) Regional dynamics and the status of amphibians. Ecology 77:2091-2097

Herrmann HL, Babbitt KJ, Baber MJ, Congalton RG (2005) Effects of landscape characteristics on amphibian distribution in a forest-dominated landscape. Biol Conserv 123:139-149

Heyer WR, Donelly MA, McDiarmid RW, Hayek LC, Foster MS (eds) (1994) Measuring and monitoring biogical diversity: standard methods for amphibians. Smithsonian Institute Press, Washington DC

Hocking DJ, Babbitt KJ (2014) Amphibian contributions to ecosystem services. Herpetol Conserv Biol 9(1):1-17

Houlahan JE, Findlay CS, Schmidt BR, Meyer AH, Kuzmin SL (2000) Quantitative evidence for global amphibian population declines. Nature 404:752-755

Isacch JP, Barg M (2002) Are bufonid toads specialized antfeeders? A case test from the Argentinian flooding pampa. J Nat Hist 36:2005-2012

Johnson CM, Johnson LB, Richards C, Beasley V (2002) Predicting the occurrence of amphibians: an assessment of multiple-scale models. In: Scott JM, Heglund PJ, Morrison ML, Haufler JB, Raphael MG, Wall WA, Samson FB (eds) Predicting species occurrences: issues of accuracy and scale. Island Press, Washington DC, pp 157-170

Johnson JB, Omland KS (2004) Model selection in ecology and evolution. Trends Ecol Evol 192:101-108

Joly P, Miaud C, Lehmann A, Grolet O (2001) Habitat matrix effects on pond occupancy in newts. Conserv Biol 15:239-248

Knutson MG, Sauer JR, Olsen DA, Mossman MJ, Hemesath LM, Lannoo MJ (1999) Effects of landscape composition and wetland fragmentation on frog and toad density and species richness in Iowa and Wisconsin, USA. Conserv Biol 13:1437-1446

Kolozsvary MB, Swihart RK (1999) Habitat fragmentation and the distribution of amphibians, patch and landscape correlates in farmland. Can J Zool 77:1288-1299

Lajmanovich RC, Peltzer PM (2004) Aportes al Conocimiento de los Anfibios Anuros con Distribución en las Provincias de Santa Fe y Entre Ríos (Biología, Diversidad, Ecotoxicología y Conservación). Temas de la Biodiversidad del Litoral fluvial argentino INSUGEO, Miscelánea 12:291-302

Legendre P, Legendre L (1998) Numerical ecology, 2nd edn. Elsevier, Amsterdam

Lehtinen RM, Ramanamanjato J (2006) Effects of rainforest fragmentation and correlates of local extinction in a herpetofauna from Madagascar. Appl Herpetol 3:95-110

LePage M, Courtois R, Daigle C (1997) Surveying calling amphibians in Quebec using volunteers. Herpetol Conserv $1: 128-140$

MacKenzie DI, Nichols JD, Hines JE, Knutson MG, Franklin AB (2003) Estimating site occupancy, colonization and 
local extinction when a species is detected imperfectly. Ecology 84:2200-2207

Mackenzie DI, Royle JA (2005) Designing efficient occupancy studies: general advice and tips on allocation of survey effort. J Appl Ecol 42:1105-1114

Manzano S, Baldo D, Barg M (2004) Anfibios del Litoral Fluvial Argentino. Temas de la Biodiversidad del Litoral fluvial argentino INSUGEO, Miscelánea 12: 271-290

Marcot BG, Vander Heyden M (2001) Key ecological functions of wildlife species. In: Johnson DH, O'Neil TA (eds) Wildlife-habitat relationships in Oregon and Washington. Oregon State University Press, Corvallis, pp 168-186

Marsh DM, Trenham PC (2001) Metapopulation dynamics and amphibian conservation. Conserv Biol 15:40-49

Martori R, Aun L, Gallego F, Rozzi Gimenez C (2005) Temporal variation and size class distribution ina a herpetological assemblage from Córdoba, Argentina. Cuad Herpetol 19(1):35-52

McDiarmid RW, Altig R (1999) Tadpoles. The biology of anuran larvae. University of Chicago Press, Chicago

McGarigal K, Cushman SA, Ene E (2012) FRAGSTATS v4: Spatial pattern analysis program for categorical and continuous maps. Computer software program produced by the authors at the University of Massachusetts, Amherst. http:// www.umass.edu/landeco/research/fragstats/fragstats.html

McGarigal K, Marks BJ (1995) FRAGSTATS: spatial pattern analysis program for quantifying landscape structure. Gen. Tech. Report PNW-GTR-351, USDA Forest Service, Pacific Northwest Research Station, Portland

Mech SG, Zollner PA (2002) Using body size to predict perceptual range. Oikos 98:47-52

Mensing DM, Galatowitsch SM, Tester JR (1998) Anthropogenic effects on the biodiversity of riparian wetlands of a northern temperate landscape. J Environ Manag 53:349-377

Naiman RJ, Décamps H, McClain ME (2005) Riparia: ecology, conservation, and management of streamside communities. Elsevier Academic Press, Burlington

Oesterheld M (2008) Impacto de la agricultura sobre los ecosistemas. Fundamentos ecológicos y problemas más relevantes. Ecol Austral 18:337-346

Opdam P (1990) Dispersal in fragmented populations: the key to survival. In: Bunce RGH, Howards DC (eds) Species dispersal in agricultural habitats. Belhaven Press, London, pp 3-17

Peltzer PM, Lajmanovich RC (2007) Amphibians. In: The middle Parana River. Limnology of a subtropical wetland. Iriondo, Martin H, Paggi, Juan César, Parma, María Julieta eds. 382 p

Peltzer PM, Lajmanovich RC, Attademo AM, Beltzer AH (2006) Anuran diversity across agricultural pond in Argentina. Biodivers Conserv 15:3499-3513

Peltzer PM, Lajmanovich RC, Sanchez LC, Attademo AM, Junges CM, Bionda CL, Martino AL, Basso A (2011) Morphological abnormalities in amphibian populations from the mid-eastern region of Argentina. Herpetol Conserv Biol 6:432-442

Pérez Leiva F, Anastasio MD (2003) Consumo de fitosanitarios en el contexto de expansión agrícola. Facultad de Agronomía, Universidad de Buenos Aires, Buenos Aires. www. agro.uba.ar/apuntes/no_5/agroquimicos.htm
Pohl C, Van Genderen JL (1998) Multisensor image fusion in remote sensing: concept, methods, and applications. Int $\mathbf{J}$ Remote Sens 19(5):823-854

Price SJ, Marks DR, Howe RW, Hanowski JM, Niemi GJ (2004) The importance of spatial scale for conservation and assessment of anuran populations in coastal wetlands of the western Great Lakes, USA. Landscape Ecol 20:441-454

Pulliam HR (1988) Sources, sinks and population regulation. Am Nat 132:652-661

QGIS Geographic Information System [internet] [QGIS Development Team] (2012) Open Source Geospatial Foundation Project. http://qgis.osgeo.org

Quesnelle PE, Lindsay KE, Fahrig L (2014) Low reproductive rate predicts species sensitivity to habitat loss: a metaanalysis of wetland vertebrates. PLoS One 9(3):e90926

R Development Core Team (2013) R: a language and environment for statistical computing. R Foundation for Statistical Computing, Vienna. http://www.R-project.org/

Rabinovich J, Torres F (2004) Caracterización de los síndromes de sostenibilidad del desarrollo. El caso de Argentina. Serie Seminarios y Conferencias. Comisión Económicas para América Latina y el Caribe (CEPAL). Documento LC/L .2155-P, Santiago

Rothermel BB (2004) Migratory success of juveniles: a potential constraint on connectivity for pond-breeding amphibians. Ecol Appl 14(5):1535-1546

Rothermel BB, Semlitsch RD (2002) An experimental investigation of landscape resistance of forest versus old-field habitats to emigrating juvenile amphibians. Conserv Biol 16:1324-1332

Sabattini RA, Ledesma S, Fontana E, Sabattini J, Diez JM, Brizuela A, Muracciole B (2009) Zonificación de los bosques nativos en el Departamento La Paz (Entre Ríos) según las categorías de conservación

Sabattini RA, Ledesma S, Muracciole B, Sabattini J (2008) Categorización de las áreas de montes nativos en departamento La Paz, Entre Ríos. Rev COPAER 26:12-15

Sabattini RA, Wilson MG, Muzzachiodi N, Dorsch AF (1999) Guía para la caracterización de agroecosistemas del centronorte de Entre Ríos. Rev Cient Agropecu 3:7-19

Sabattini RA, Ledesma S, Sabattini JA, Fontana E, Diez JM, Sabattini I (2010) Zonificación de losbosques nativos de los Departamentos Paraná, Nogoyá y Tala (Entre Ríos) según las categorías de conservación: Informe V. Oro Verde, Entre Ríos, UNER. 38 p

Schrag AM, Zaccagnini ME, Calamari N, Canavelli S (2009) Climate and land-use influences on avifauna in central Argentina: broad-scale patterns and implications of agricultural conversion for biodiversity. Agric Ecosyst Environ 32(1-2):135-142

Seale DB (1980) Influence of amphibian larvae on primary production, nutrient flux and competition in a pond ecosystem. Ecology 61:1531-1550

Secretaría de Agricultura, Ganadería, Pesca y Alimentos [SAGPYA] (2014) http://informes.acabase.com.ar/Lists/ SAGPYA\%202012/AllItems.aspx

Semlitsch RD, Bodie JR (2003) Biological criteria for buffer zones around wetlands and riparian habitats for amphibians and reptiles. Conserv Biol 17:1219-1228 
Shirose LJ, Bishop CA, Green DM, MacDonald CJ, Brooks RJ, Helferty NJ (1997) Validation tests of an amphibian call count survey technique in Ontario, Canada. Herpetologica 53:312-320

Silva FR, Oliveira TAL, Gibbs JP, Rossa-Feres DC (2012) An experimental assessment of landscape configuration effects on frog and toad abundance and diversity in tropical agro-savannah landscapes of southeastern Brazil. Landscape Ecol 27:87-96

Sinsch U (1990) Migration and orientation in anuran amphibians. Ethol Ecol Evol 2:65-79

Sparling DW (2002) A review of the role of contaminants in amphibian declines. In: Hoffman DJ, Rattner BA, Allen Burton G Jr, Cairns J Jr (eds) Chapter 40: Handbook of ecotoxicology. CRC Press, Boca Raton, pp 1099-1127

Straneck R, de Olmedo EV, Carrizo GR (1993) Catálogo de voces de anfibios argentinos. Parte 1. Buenos Aires, LOLA

Suárez RP, Zaccagnini ME (2004) Anuros asociados a campos de soja y la importancia de la heterogeneidad espacial. Libro de Resúmenes de la Reunión Binacional de Ecología 2004, Mendoza

Tassi H, Wilson M, Schulz G, Indelangelo N, Bedendo D (2011) Uso de la Tierra en el área de bosques nativos de Entre Ríos. http://inta.gob.ar/documentos/uso-de-la-tierra-en-elarea-de-bosques-nativos

The IUCN Red List of Threatened Species (2015) Version 2014.3 [IUCN 2014.3] February 2015. www.iucnredlist. org

Trenham PC, Shaffer HB (2005) Amphibian upland habitat use and its consequences for population viability. Ecol Appl 15(4):1158-1168

Vaira M, Akmentins MS, Attademo M, Baldo D, Barrasso D, Barrionuevo S, Basso N, Blotto B, Cairo S, Cajade R, Céspedez J, Corbalán V, Chilote P, Duré M, Falcione C, Ferraro D, Gutierrez FR, Ingaramo MR, Junges C, Lajmanovich R, Lescano JN, Marangoni F, Martinazzo L, Marti R, Moreno L, Natale GS, Perez Iglesias JM, Peltzer P, Quiroga L, Rosset S, Sanabria E, Sanchez L, Schaefer E, Úbeda C, Zaracho V (2012) Categorización del estado de conservación de los anfibios de la República Argentina. Cuad Herpetol 26(Suppl. 1):131-159

Veysey JS, Mattfeldt SD, Babbitt KJ (2011) Comparative influence of isolation, landscape, and wetland characteristics on egg-mass abundance of two pool-breeding amphibian species. Landscape Ecol 26:661-672

Viglizzo EF, Le'rtora FA, Pordomingo AJ, Bernardos J, Roberto ZE, Del Valle H (2001) Ecological lessons and applications from one century of low external-input farming in the pampas of Argentina. Agric Ecosyst Environ 81:65-81

Viglizzo EF, Pordomingo AJ, Castro MG, Lertora FA (2003) Environmental assessment of agriculture at a regional scale in the pampas of Argentina. Environ Monit Assess 87:169-195

U.S. EPA (2002) Methods for evaluating wetland condition: using amphibians in bioassessments of wetlands. Office of Water, U.S. Environmental Protection Agency, Washington, DC. EPA-822-R-02-022

Weir LA, Mossman MJ (2005) North American Amphibian Monitoring Program (NAAMP). In: Lannoo M (ed) Amphibian declines: conservation status of United States amphibians. University of California Press, Berkeley, pp 307-313

Williams BK (2008) A multi-scale investigation of ecologically relevant effects of agricultural runoff on amphibians. $\mathrm{PhD}$ Dissertation, Faculty of the Graduate School at the University of Missouri, Columbia

Wyman RL (1998) Experimental assessment of salamanders as predators of detrital food webs: effects on invertebrates, decomposition and the carbon cycle. Biodivers Conserv 7:641-650

Young S (2006) Agriculturalization as a syndrome: a comparative study of agriculture in Argentina and Australia. Serie Medioambiente y desarrollo $\mathrm{N}^{\circ} 125$. Comisión Económicas para América Latina y el Caribe (CEPAL)

Zaccagnini ME, Bernardos J, Gonzalez C, Calamari N, De Carli R (2007a) Evaluación del Riesgo ecotoxicológico para aves por insecticidas usados en cultivos de Entre Ríos: un indicador de calidad ambiental. In: Caviglia OP, Paparotti OF, Sasal MC (eds) Agricultura Sustentable en Entre Ríos. INTA, Buenos Aires, pp 127-136

Zaccagnini ME, Decarre J, Goijman A, Solari L, Suárez R, Weyland F (2007b) Efecto de la heterogeneidad ambiental de terrazas y bordes vegetados sobre la biodiversidad animal en campos de soja en Entre ríos. In: Caviglia OP, Paparotti OF, Sasal MC (eds) Agricultura Sustentable en Entre Ríos. INTA, Buenos Aires, pp 159-171

Zollner PA (2000) Comparing the landscape level perceptual abilities of forest sciurids in fragmented agricultural landscapes. Landscape Ecol 15:523-533

Zuur AF, Ieno EN, Walker NJ, Saveliev AA, Smith GM (2009) Mixed effects models and extensions in ecology with R. Sprimger, New York 